\title{
Digital Transformation of Russian Enterprise and Human Capital Development: Challenges and Opportunities
}

\author{
Seliverstov Yu.I. ${ }^{*}$ Moiseev V.V. Komarova O.A. \\ Belgorod State Technological University. V.G. Shukhov, Belgorod, Russia \\ *Corresponding author. Email: din_prof@mail.ru
}

\begin{abstract}
In a modern economy, information plays a dual role. On the one hand, it acts as a factor of production (resource), on the other hand, as a personal good (product). The digital economy is characterized by the fact that traditional factors of production (capital, labor, land) are supplemented with a new factor - information technology, which is becoming a key factor in all areas of socio-economic development. It is possible to become a leader in the digital transformation of the economy only through significant changes in the approach to the development of human capital. The article considers challenges and problems that Russian business and society faced when entering the era of the digital economy, primarily in terms of human capital development. The approaches of various researchers to the process of digital transformation of the business are examined, the directions and content of the main activities in the framework of the "Personnel for the Digital Economy" federal project are analyzed.
\end{abstract}

Keywords: digital economy, digital transformation, human capital, information, education, federal project

\section{INTRODUCTION}

Modern digital technologies (Big Data, Internet of Things, artificial intelligence, robotics, cognitive services) are actively introduced in all sectors of the global economy. The transition to the "digitalization" era radically changes the situation in a number of key areas, namely:

- information becomes a key resource;

- the company does not need to be big in order to compete successfully;

- development trends are dictated by the consumer.

A prerequisite for maintaining competitiveness in a rapidly changing market is the digital transformation of business entities, that is, a radical change in their business strategy and business processes under the influence of digitalization. Digital technologies can lead to large-scale changes due to the fact that such technologies become available to most companies almost immediately after development and implementation. However, this accessibility factor indicates that almost any company can use digital technology, but can not always create a competitive advantage. Therefore, we can assume that the main thing in the digital transformation of a business is its significant differentiation, in order to offer consumers new and attractive products, the appearance of which was made possible thanks to digital technologies.

The International Data Corporation (IDC) international research company defines digital transformation as the approach by which enterprises change their business models and business ecosystems using digital technologies and competencies [1].

V.D. Markova considers the digital transformation of business as the process of turning a traditional organization into a digital company, in the activity of which there are both material and digital objects (a digital counterpart of a technically complex product, an online store, a company's website, etc.) [2].

According to scientists from the Russian Economic University named after V.G. Plekhanov O.V. Kitova and S.N. Bruskin, digital transformation involves the transformation of existing companies into so-called "digital enterprises", which should operate on new business, economic and managerial principles, the most important of which is the relationship between consumers and organizations. Russian companies should proceed to the systematic creation of a digital business model, which will provide a strategic advantage from digital technologies. [3]. Consequently, digital transformation is not just a transition from analog data and its media to digital. There is transformation of the supply and demand combining principles, allocation of resources, production and consumption. New needs, industries and markets are being created, the boundaries 
status and development of digital infrastructure published in periodicals and specialized literature.

economic system begins to transform [4].

E.V. Shirinkina defines the directions of industrial enterprises activity in the development of digitalization as following [5]:

- digital technologies should be introduced into production activities at a faster pace;

- $\quad$ enterprises should work closely with government agencies, educational and research organizations in the design and development of new digital technologies;

- it is recommended to review the policy of investing in human capital and in digital solutions;

- enterprises should develop long-term human capital management strategies with digitalization in mind.

Thus, it can be argued that in the digital economy, human capital is becoming a key factor of production. The accelerated development of technology makes it necessary to update professional knowledge through a process of continuous learning, the acquisition of new competencies and advanced training.

\section{PURPOSE AND OBJECTIVES OF THE STUDY}

This paper explores the challenges and problems that Russian business and society faced when they entered the era of the digital economy, primarily in terms of the development of human capital. The task is to consider and analyze the directions and content of the main activities in the framework of the "Personnel for the Digital Economy" federal project implementation.

\section{METHODS}

The studies were carried out in the second half of 2019 at the Department of Economics and Organization of Production of Belgorod State Technological University named after V.G. Shukhov. The theoretical and methodological basis of the study was the fundamental principles of the evolutionary theory of economic change. In the process of developing the research problems, universal methods of scientific knowledge and special methods of integrated economic analysis were applied.

The information and empirical base of the study was formed on the basis of data from the Ministry of Science and Higher Education and the Ministry of Digital Development of the Russian Federation, the official websites of the President and the Government of the Russian Federation, as well as information materials on the

\section{MAIN PART}

In accordance with the "Strategy for the Scientific and Technological Development of the Russian Federation", approved by Decree of the President of the Russian Federation No. 642 dated December 1, 2016, one of the main challenges of our time is "the exhaustion of Russia's economic growth opportunities, based on extensive exploitation of raw materials, against the background of the digital economy formation and the emergence of a limited group of leading countries with new manufacturing technologies, which are focused on the use of renewable resources" [6]. Based on the current economic situation analysis, we can formulate some of the challenges that today arise for Russian entrepreneurs and society

1. Digital literacy. People, as a rule, either do not know about the opportunities provided by digital technologies, or do not know how to use them. Now most of the economy is on analog rails, and the organization of labor, including a large number of enterprises, does not require a person to know modern digital technologies. Further technological development, labor automation, and the digitalization of familiar activities leads to the growing demand for not only competencies, but also digital literacy. We can define digital literacy as the ability to create and use content using digital technology, including computer programming skills, searching and sharing information, and communicating with other people. So, by 2021 , at least $40 \%$ of the population should have the appropriate skills for working with digital technologies.

2. Continuing education. According to international experts, $65 \%$ of those who are currently in primary school will be engaged in activities that have not yet been invented [7]. The digital economy is fundamentally changing the labor market, especially since digital technologies provide new opportunities for organizing and developing a business. In the near future, a regular change of profession will become the norm, and being in the same professional field will more and more require readiness for training. The concept of lifelong education assumes that a person's life is not strictly divided into the period of study (before receiving a diploma) and work. It considers learning as a constant process throughout life.

3. Individualization of education. At present, there is a strengthening of individual trajectories in education. Citizens and corporations present their specific requirements for the competencies that higher education should represent. Experts are confident that the digital economy will require a person to develop skills of selforganization, planning, self-motivation - and this is facilitated by the individualization of education.

4. Training for work in the field of information technology (IT). Today in Russia, the need for specialists in the field of IT is 400 thousand people. However, universities train regarding the development of human capital. 
only 45 thousand specialists in this field per year. The vocational education system should begin as soon as possible to provide the economy with the necessary personnel with digital competencies to eliminate the existing shortage of specialists.

5. Formation of the market for educational technologies. The total size of the education market in the world is about $\$ 6,000$ billion per year. The online education segment in total terms is 3\%, reached $\$ 165$ billion by 2017 and continues to grow [8]. In 2017 alone, global investors invested more than $\$ 8$ billion in it, largely due to the countries of the Asian region (India, China) and the countries of South America. Experts suggest that in 2020, $54 \%$ of the educational technology market will be in actively developing countries.

The Russian educational technology market is at the formation stage and, as of the beginning of 2017, according to expert estimates, amounted to $\$ 0.3$ billion (21 billion rubles) in monetary terms, with the total education market in the Russian Federation at \$29 billion ( 1,800 billion rubles), i.e. a little over $1 \%$.

6 . The challenges that have arisen in the education system should be highlighted [9]:

- only $14.9 \%$ of the population over 16 have the skills to solve problems in a technologically complex environment, which is significantly lower than the indicator for OECD countries;

- only $8.2 \%$ of high school students choose the technical field from all for which specialized education in high school is carried out;

- only $5.5 \%$ of students in continuing education organizations are engaged in technical or sportstechnical associations;

- in the structure of Russian higher and secondary vocational education programs, there is practically no "digital component" when, in developed countries, it is assumed that in the coming years three quarters of all vacancies in STEM (natural and computer sciences, technology, mathematics) will be about digital economy

- there is not only a large lag in the scientific fields in which new digital technologies are being formed in Russia, but also a large lag in the content and technologies for training of advanced specialists in digital technologies, which is reflected in outdated courses in mathematics, informatics and computer science;

- hundreds of universities continue to train specialists who do not meet modern world standards.

Without any doubts, these challenges cannot remain out of sight of the authorities, the scientific and expert community, and citizens. It is impossible to meet them without significant changes in the entire educational environment and, first of all, in the system of higher professional education.

As already noted, the digital economy marks the transition to a fundamentally new business model. In today's world, competition in assets and financial resources has been replaced by competition of human capital. At the same time, personnel began to turn into the most significant limiting factor. One of the main barriers to the digital transformation of an organization can be a shortage of employees with digital skills and the ability to work with advanced technologies.

By the Decree of the President of the Russian Federation dated May 07, 2018 No. 204 "On National Goals and Strategic Tasks of the Development of the Russian Federation for the Period Until 2024", the Government of the Russian Federation, when implementing the national program "Digital Economy of the Russian Federation", is entrusted with ensuring the fulfillment of a number of tasks in 2024, in including: transformation of priority sectors of the economy and the social sphere, including healthcare, education, industry, agriculture, construction, urban economy, transport and energy infrastructure, financial services, through the introduction of digital technology and platform solutions. [10]

One of the priority areas of work is the implementation of the "Personnel for the Digital Economy" federal project (hereinafter referred to as the federal project), which is aimed at ensuring the training of highly qualified personnel for the digital economy. Its main goal is to provide the domestic economy with a sufficient amount of human resources with the competencies necessary for the new century of digital technologies and the knowledge economy. The key areas of the federal project are:

- providing the digital economy with competent personnel;

- $\quad$ support for talented schoolchildren and students in the field of mathematics, computer science and technology of the digital economy;

- $\quad$ assisting citizens in the development of digital literacy and the competencies of the digital economy.

In particular, the implementation of the "Providing the digital economy with competent personnel" includes activities in the following areas.

1. Development of a competency model for the digital economy, a profile of competencies and a personal development path

Within the framework of the program, it is planned to develop a model of competencies in the digital economy a list of key competencies necessary for each citizen for effective professional and everyday activities in the digital economy. This model will complement the existing requirements for competencies inherent in educational programs and requirements for the implementation of professional activities. At the same time, the main step in 
working with a large number of existing and new competency models in both the field of traditional education and corporate will be data exchange and synchronization protocols between different competency models and systems for recording professional and educational results, in order to integrate the obtained data on achievements person.

To facilitate the development of each Russian's digital competencies, a format for a personal competency profile will be prepared. A personal profile of competencies is a kind of "passport" of knowledge, skills, competencies, accumulated experience and various achievements of a person that will allow analyzing personal competitiveness in the labor market, identify missing competencies, and plan measures for their acquisition or development. Certification of competencies will be carried out not only through formal procedures (exam, test, etc.), but also using independent certification formats, which will be performed by independent operators and the results of which will be included in the profile of human competencies. It is planned that in 2020 a personal profile of competencies and a personal development path will be available to every Russian student.

The personal development path is the final critical element of the general system of building human capital in the digital economy and represents a continuous digitized "path" of human development in educational and labor activities. In the framework of vocational guidance, planning an educational path, a personal development trajectory will fix all points on the path to achieving the planned goal, personally for the needs of each person. It is expected that in 2024 personal educational trajectories will be formed in all educational organizations of the country.

2. Improving vocational education programs, creating new training formats to meet the need for new specialists

The program provides already in 2019 to approve new admission target numbers to meet the needs of the digital economy in specialists, as well as launch projects at leading universities to implement new educational programs and models that are not fully covered by existing regulatory restrictions.

Given the speed of the changing landscape and the requirements for specialist knowledge, the content of many higher education programs becomes obsolete until the moment they are completed. It is proposed to pilot a new type of educational programs of higher education lasting up to 2 years (analogues of Associate's degree, half-bachelor) for at least 10 specialties of the digital economy.

The reduction of a large number of jobs in connection with the automation and digitalization of work processes creates the need to organize conditions for self-employment and entrepreneurial activity of the population. For the development of entrepreneurial and business competencies of the population, it is envisaged to normatively secure the right to use a startup created by a student as a final qualification work, as well as to ensure the development of a network of school and student business incubators, accelerators in various cities of Russia.
3. Changing the labor system to increase its flexibility, timely meeting the demands of companies for modern skilled labor, effective retraining of adults

Experts note that recently the value of a diploma in the labor market has been leveled, and employers are guided by an independent assessment of the skills of future employees. The idea of getting a profession that will be in demand throughout life does not meet the pace of the modern world: industries and professions change faster than the educational cycle ends. $81 \%$ of employers in Japan, $71 \%$ in Brazil, 50\% in Australia, 48\% in India and New Zealand report difficulties in selecting candidates with the necessary skills [11]

The trajectory of development will be used by man not only in the process of education, but also throughout his career path. It is planned to create a mechanism that will allow employers to formulate and enter the results of an internal assessment into the profile of a person's competencies, as well as use their development path as a legitimate resume with confirmed results from past jobs. This tool will ensure the continuity of employee achievements and help make informed hiring decisions.

Transparency of the requirements will facilitate the formation of an order for educational retraining programs and additional training for employees. In addition to the interests of a particular employer, digital career trajectories will make it possible to form teams for the implementation of state-scale projects due to the availability of information on the competencies and skills of the able-bodied population.

Launching the processes of digital transformation of enterprises and industries will require retraining of already working specialists. Systemic changes in state and municipal government, social sectors, can be implemented if there are managers and specialists in the state and municipal government system who are knowledgeable about digital solutions and have the necessary competencies in the digital economy. New training models and programs developed as part of the federal project will allow more than 1 million working citizens to be trained. The digital transformation of enterprises and organizations, state and municipal government is based on data management. Chief Data Officer (CDO) must be the driving force behind change. The transition to a digital economy will lead to a sharp increase in the need for such specialists who are able to make changes at all levels of the organization, giving priority to data management. Today, satisfaction with managers who are able to manage data in the public administration system is $1-2 \%$.

Within the framework of the federal project, the country's leading educational organizations plan to develop programs and provide training for managers and teams of CDO managers. It is assumed that 30 thousand people in 2019, 66 thousand in 2020, 105 thousand in 2021, 145 thousand in 2022, 220 thousand in 2023, 270 thousand in 2024 will be covered as a result of the educational programs for advanced training and retraining of the working-age population, managers and teams of CDO managers, employees of state authorities and local self- 
government bodies with digital skills and technologies in accordance with the requirements of the digital economy. 4. Creating a venture fund to support advanced educational technologies in the digital economy

The market for educational technologies is one of the most promising in Russia, since on the one hand it is not saturated with solutions, and on the other it is under pressure from aggressively growing demand. Considering that the penetration rate of online technologies in education in the world is about $3 \%$, even with a conservative estimate of the growth rate, the Russian market of educational technologies over the horizon of 3 years could grow to $\$ 1.1$ billion ( 70 billion rubles).

It is important to note that government stimulation is one of the key factors in its development. So, for example, today $47 \%$ of transactions in the field of educational technologies in the Russian Federation are carried out by funds created as part of government initiatives. As part of the federal project, a venture fund should be created to support advanced educational technologies in the digital economy (including the development of an independent assessment system for the quality of competencies in the digital economy, the selection and support of educational startups). It is planned that within five years, starting in 2019, 200 educational projects will be supported as part of the venture fund.

5. Support for talented students in mathematics, computer science and digital economy technologies

Many experts say that in the next 10 years, the structure of the labor market will undergo a serious transformation. It is assumed that in 10 years at least $15 \%$ of current jobs will cease to exist, fundamentally new professions will appear, and a number of economic sectors based on technology updates will increase their productivity significantly. Therefore, it is necessary to take measures today so that in the future we can solve the problems of technological modernization, both in the field of production of high-tech products and in the field of their use, and ensure the full establishment of a globally competitive digital economy.

The Government of the Russian Federation and the Ministry of Science and Higher Education plan to achieve this goal:

2019 - creation of a system for identifying, supporting and developing talents in the fields of mathematics, computer science, and digital technologies for the development of the digital economy;

2019-2024 - implementation of a pilot project to develop, test and implement digital training complexes and educational stimulators, virtual laboratories for the study of mathematics, computer science, technologies relevant to the problems of the digital economy, and to develop models for organizing training using digital technologies in mathematics, computer science, technologies that meet the challenges of the digital economy - the Digital University model;

2023 - elements of the Digital University model should be introduced in all state educational institutions of higher education;
2019-2024 - creation of a network of international scientific and methodological centers (ISMCs) for the preparation of highly qualified professors and teachers and the dissemination of international best practices in the teaching of mathematics, computer science, and technologies that are relevant to the tasks of the digital economy, including for educational institutions of higher education that show poor results in the educational institutions of higher education effectiveness monitoring; 2021 - start of 5 ISMCs functioning to conduct research, study and disseminate the best international practices for training, retraining and internships for advanced personnel in the digital economy in mathematics, computer science, and technology; in the future, by 2024, it is planned to create 50 centers for accelerated training in competencies digital economy (of which 15 centers in 2021), each of which will create material and technical conditions for the implementation of advanced training programs at least less than 15 IT and digital competencies.

6. Assisting citizens in the development of digital literacy and the competencies of the digital economy

Currently, on average in Russia, the costs of employers to train employees are 10 times less than in Europe. 15\% of the working population and $1 \%$ of pensioners participate in educational programs in our country. For comparison, in developed countries this is $40 \%$ and $5 \%$, respectively [12]. A system of personal digital certificates will be created for retraining the adult population. It will allow citizens to undergo retraining programs and gain 21 st century skills. Distribution of certificates on a competitive basis will become a lever of motivation, exceeding the interest of the population in acquiring new competencies. An example of such an initiative is the Skills Future program in Singapore. Each year, the Government of Singapore distributes up to 2000 certificates with a face value of $\$$ 5,000 to retrain citizens of the skills of the 21 st century [13].

It is planned that in order to ensure the wide availability of courses in the digital economy competencies, a publicly available free online continuing education service for the digital literacy development for various layers of the working population will be created in 2019. In 2019-2024 1000 thousand people will be trained in the development of digital economy competencies within the framework of the state system of personal digital certificates and 10 million people will be trained in online digital literacy development programs.

\section{CONCLUSIONS}

1. The implementation of the planned activities certainly should bring a positive result in the development of human capital, will create key conditions for training the digital economy and the transition of Russia to a new technological structure.

If the federal project is successfully implemented, by 2024 at least 800 thousand graduates of the vocational education 
[5] Ye.V. Shirinkina, Osobennosti

system will have the basic competencies of the digital economy, and at least 120 thousand graduates of the higher education system will be trained in IT specialties. The share of the population with digital skills will be at least $40 \%$ by 2021 . Russia should rise in the ranking of talent attraction The Global Talent Competitiveness Index from 52 to 30 place.

2. In the face of intense global competition and severe resource constraints, a way out of the current situation requires prioritization among the possible directions of transformations of the education system in the short and medium term. One of the key priorities is to create the conditions for identifying support and development of talents in the field of mathematics, computer science, and digital technologies for the development of the digital economy.

3. Such large-scale reforms are unlikely to be implemented if they are implemented by people with old thinking. The new economy certainly requires a fundamental change in managerial culture. Characteristic features of the new management culture should be:

- $\quad$ promotion of any initiative;

- lack of hard dogma and action algorithms;

- decision making based solely on objective data;

- The main results of management activities should not be bureaucratic procedures and the expenditure of public funds, but a mutually beneficial partnership in which the focus is on the person.

\section{ACKNOWLEDGMENT}

The reported study was funded by RFBR, project number 19-29-07024.

\section{REFERENCES}

[1] What Is Leadership Digital Transformation / Paragon. Available at: http://www.consultparagon.com/ blog/what-is-leadership-digital-transformation

[2] V.D. Markova, Vliyaniye tsifrovoy ekonomiki na biznes // EKO: vserossiyskiy ekonomicheskiy zhurnal. - 2018. № 12. - s. 7-22.

[3] O.V. Kitova, Tsifrovaya transformatsiya biznesa / O.V. Kitova, S.N. Bruskin // Tsifrovaya ekonomika. - № 1 (1). - s. 20-25.

[4] M.V. Safronchuk, Tsifrovaya postup' revolyutsii (chetvertaya promyshlennaya revolyutsiya $\mathrm{i}$ tsifrovaya trans-formatsiya // Ekonomika i upravleniye: problemy, resheniya. - 2017. - № 11, T. 5. - s. 52-56. funktsionirovaniya promyshlennykh predpriyatiy $\mathrm{v}$ tsifrovoy ekonomike // Ekonomika v promyshlennosti. 2018. Tom 11. - № 2-3. - s. 143-148.

[6] Ukaz Prezidenta Rossiyskoy Federatsii \&quot;O strategii nauchno-tekhnicheskogo razvitiya Rossiyskoy Fede-ratsii\&quot; ot 1 dekabrya 2016 g. Number 642. Available at: http://www.consultant.ru/document/cons_doc_LAW_2 07967/

[7] Now You See It: How the Brain Science of Attention Will Transform the Way We Live, Work and Learn. Cathy Davidson, 2011.

[8] A. Krechetova, Budushcheye onlaynobrazovaniya v Rossii: rost i ostorozhnyye investitsii. Available at: https://www.forbes.ru/tehnologii/342961

[9] Pasport federal'nogo proyekta «Kadry dlya tsifrovoy ekonomiki». Available at: https://legalacts.ru/ doc/pasport-federalnogo-proekta-kadry-dlja-tsifrovoiekonomiki-utv-prezidiumom/

[10] Ukaz Prezidenta RF ot 07 maya 2018 g. № 204 «Ob osnovnykh tselyakh i strategicheskikh zadachakh razvitiya Rossiyskoy Federatsii na period do 2024 goda». Available at: http://kremlin.ru/acts/news/57425

[11] World Economic Forum (2011) "Global Talent Risk Report: Seven Responsens". Available at: https:// www.weforum.org/reports/global-talent-risks-report2011

[12] P. Luksha, J. Cubista, M. Popovich, A. Laszlo, I. Ninenko, A Vision of Societal Transformation Though Educational Ecosystems jf the 21 st Century. Global Education Futures Report, April 2017.

[13] A. Shvindt, Otsifrovannoye budushcheye. Available at: http://pressa.ru/ru/top10/detail/otsifrovannoebuduschee-10192\#/ 